\title{
Cytotoxicity of Cheese and Cheddar Cheese food flavorings on Allim cepa $\mathrm{L}$ root meristems
}

\author{
A. G. Moura ${ }^{a}$, G. M. Santana ${ }^{a}$, P. M. P. Ferreira ${ }^{b}$, J. M. C. Sousa $a^{a}$ and A. P. Peron Pe* $^{a,}$ \\ ${ }^{a}$ Núcleo de Pesquisa Aplicada a Saúde e ao Meio-ambiente - NUPBSAM, Laboratório de Citogenética Vegetal e \\ Animal - LCVA, Universidade Federal do Piauí - UFPI, Campus Senador Helvídio Nunes de Barros - CSHNB, \\ Rua Cícero Duarte, 940, Bairro Junco, CEP 64607-670, Picos, PI, Brazil \\ 'Laboratório de Cancerologia Experimental - LabCancer, Departamento de Biofísica e Fisiologia, Centro de Ciências da \\ Saúde - CCS, Universidade Federal do Piauí - UFPI, Campus Ministro Petrônio Portella - CMPP, Bairro Ininga, \\ CEP 64049-550, Teresina, PI, Brazil \\ 'Programa de Pós-graduação em Genética e Melhoramento - PPGM, Centro de Ciências Agrárias - CCA, \\ Universidade Federal do Piauí - UFPI, Campus Ministro Petrônio Portella - CMPP, Bairro Ininga, lado ímpar, \\ CEP 64049-550, Teresina, PI, Brazil \\ *e-mail: anapaulaperon@ufpi.edu.br
}

Received: September 30, 2014 - Accepted: March 5, 2015 - Distributed: May 31, 2016

\begin{abstract}
Despite their great importance for the food industry, flavorings, in general, raise a number of questions regarding their cytotoxicity, mutagenicity and carcinogenicity, since, in the literature, there are few studies found evaluating the toxicity on the systemic and cellular level, of these chemical compounds. The root meristems of Allium cepa (onion) are widely used for the assessment of toxicity of chemical compounds of interest. Thus, this study aimed to evaluate, in A. cepa meristematic cells, individually and in combination at the cellular level, the toxicity of synthetic Cheese and Cheddar Cheese food flavorings, identical to the natural, at doses of 1.0 and $2.0 \mathrm{~mL}$, at exposure times of 24 and 48 hours. In combination we used $0.5 \mathrm{~mL}$ of Cheese flavor associated with $0.5 \mathrm{~mL}$ of Cheddar flavor; and $1.0 \mathrm{~mL}$ of Cheese flavor associated with $1.0 \mathrm{~mL}$ of Cheddar flavor, at exposure times of 24 and 48 hours. For these evaluations, we used groups of five onion bulbs, which were first embedded in distilled water and then transferred to their respective doses. The root tips were collected and fixed in acetic acid (3:1) for 24 hours. The slides were prepared by crushing and were stained with $2 \%$ acetic orcein. Cells were analyzed throughout the cell cycle, totaling 5,000 for each control and exposure time. The mitotic indices calculated and cellular aberrations observed were subjected to statistical analysis using the chi-square test $(\mathrm{p}<0.05)$. No chromosomal abnormalities nor those of mitotic spindle were observed for the treatments performed. The results, both individually and in combination, showed that the flavorings under study significantly reduced the cell division rate of the test system cells used. Therefore, under the conditions studied, the two flavorings were cytotoxic.
\end{abstract}

Keywords: food additive, toxicity, cell cycle, test-plant system.

\section{Citotoxicidade de aromatizantes alimentares de Queijo e Queijo Cheddar sob meristemas de raízes de Allim cepa $\mathrm{L}$}

\section{Resumo}

Apesar da grande importância para a indústria alimentícia, os aromatizantes, em geral, suscitam uma série de dúvidas quanto a sua citotoxicidade, mutagenicidade e carcinogenicidade, visto que, na literatura, poucos são os trabalhos encontrados avaliando a toxicidade, em nível sistêmico e celular, destes compostos químicos. Os meristemas de raízes de Allium cepa (cebola) são muito utilizados para a avaliação da toxicidade de compostos químicos de interesse. Desta forma, este trabalho teve por objetivo avaliar em células meristemáticas de $A$. cepa, de forma individual, a toxicidade em nível celular de aromatizantes alimentares sintéticos, idênticos aos naturais, de sabores Queijo e Queijo Cheddar, nas doses de 1,0 e 2,0 mL, nos tempos de exposição de 24 e 48 horas; e de forma associada, onde se utilizou 0,5 mL do aromatizante sabor Queijo associado a $0,5 \mathrm{~mL}$ do aromatizante sabor Queijo Cheddar; e 1,0 $\mathrm{mL}$ do aromatizante sabor Queijo associado a 1,0 mL do aromatizante sabor Queijo Cheddar, nos tempos de exposição de 24 e 48 horas. Para estas avaliações utilizou-se grupos de cinco bulbos de cebolas, que primeiramente foram enraizados em água destilada, e em seguida transferidos para as suas respectivas doses. As radículas foram coletadas e fixadas em ácido acético (3:1) por 24 horas. As lâminas foram preparadas pela técnica de esmagamento e coradas com orceína acética a $2 \%$. Analisaram-se células em todo ciclo celular, totalizando 5.000 para cada controle e tempo de exposição. Os índices mitóticos calculados e as aberrações celulares observadas foram submetidos à análise estatística do Qui-quadrado 
$(\mathrm{p}<0,05)$. Não foram observadas alterações cromossômicas e anomalias de fuso mitótico para nenhum dos tratamentos realizados. Os resultados obtidos, tanto individualmente como de forma associada, mostraram que os aromatizantes em estudos reduziram de forma significativa os índices de divisões celulares das células do sistema teste utilizado. Portanto, nas condições analisadas, os dois aromatizantes foram citotóxicos.

Palavras-chave: aditivo alimentar, toxicidade, ciclo celular, sistema-teste vegetal.

\section{Introduction}

Flavorings are food additives with aromatic and/or sapid properties capable of conferring or enhancing the aroma and flavor of foods without providing nutrition (Constant et al., 2007). They are classified as natural, synthetic identical to natural, synthetic artificial, reaction or conversion flavorings, and smoke flavorings (Honorato et al., 2013).

Diluents, antioxidants, defoamers, preservatives, emulsifiers, stabilizers, acidity regulators, flavor enhancers, anti-humectants, anti-caking agents, dyes, and extraction and processing solvents are present in the formulation of these additives approved for worldwide use by the European Food Safety Authority (EFSA), and nationally by the National Agency for Sanitary Vigilance (ANVISA, 2007).

However, due to the complex chemical formulation, flavorings, in general, are considered a controversial advancement of the food industry by many healthcare experts who claim that these compounds, along with food dyes, significantly contribute to the dietary impoverishment and the triggering or potentiation of pathologies (Cheeseman, 2012). Thus, researchers such as Shibamoto (2014), have reported that the use of flavorings, mainly synthetic, raises a number of questions regarding their toxicity on the systemic and cellular level, and declare that the carrying out of studies to properly evaluate the toxic potential of these flavors are necessary and urgent; confirming the appeal of ANVISA (2007), itself, for the improvement of the safe use of additives in the constitution of food to be constant and prioritary.

Bioassays with plants have been considered highly sensitive and simple for the monitoring of chemical compound cytotoxic effects (USEPA) (Iganci et al., 2006) and Allium cepa (onion) has been indicated as an effective test organism for evaluating toxicity at the cellular level (Caritá and Marin-Morales, 2008) due to its kinetic properties of proliferation, for having large chromosomes and few in number $(2 n=16)$, which facilitates their analysis in the detection of micronuclei and mitotic spindle abnormalities (Herrero et al., 2012) as well as the verification of changes in the cell division rate (mitotic index) (Tabrez et al., 2011). According to Caritá and Marin-Morales (2008) the Allium system is an efficient bioassay for the initial cytotoxicity and mutagenicity screening of chemical compounds.

Furthermore, in most cases this test system demonstrates satisfactory similarity to the results obtained with other bioassays (Arung et al., 2011). As an example one can cite the work by Gomes et al. (2013) and Oliveira et al. (2013) who evaluated the toxic potential of dyes widely used in the food industry on A. cepa meristematic root cells and obtained results similar to those obtained in animal-system testing and in cell cultures.

In this context, this work aimed to evaluate the toxicity of Cheese and Cheddar Cheese savory synthetic food flavorings, identical to natural, individually and in combination, to A. cepa meristematic root cells at the cellular level. These food flavorings are widely used in the food industry in frozen meals, crackers, snacks and breads, and widely consumed by the population.

\section{Material and Methods}

\subsection{Obtaining the flavorings and definition of study doses}

Cheese and Cheddar Cheese flavor synthetic savory liquid food flavorings, identical to the natural, were obtained from a retailer, located in northeastern Brazil, specialized in the national and international commercialization of synthetic food additives. The flavorings, with an oily appearance, were packaged in $100 \mathrm{~mL}$ amber bottles and were within the expiration date. The label on these additives suggested the use of $1.0 \mathrm{~mL}$ of flavoring in $300 \mathrm{~g}$ of dough. Thus, we selected large onion bulbs with an average of $300 \mathrm{~g}$ and established a test doses of 1.0 and $2.0 \mathrm{~mL}$ for the two flavorings studied.

The doses established for these two food additives were also evaluated individually and in combination, as follows: $0.5 \mathrm{~mL}$ of the Cheese flavor associated with $0.5 \mathrm{~mL}$ of Cheddar cheese flavor; $1.0 \mathrm{~mL}$ of the Cheese flavor combined with $1.0 \mathrm{~mL}$ of the Cheddar cheese flavor. The associated evaluation manner was conducted because the Cheese and Cheddar flavorings are widely used in combination in the preparation of processed foods.

It is important to clarify that for the cytotoxicity and mutagenicity evaluation of the flavorings in question, individually and in combination, no dilution was performed to define the doses, i.e., the intention was to verify their toxicity to A. cepa root meristems directly in the solution present in the product vials. We chose to do it this way out of concern that the concentration of the compounds present in the flavorings could be changed since they have a complex chemical formulation.

It is also important to report, as EFSA states, that the formulation of any natural or synthetic food flavoring is standardized worldwide, with no changes in chemical formulations for different product brands. However, this regulatory agency, as well as the manufacturers of food additives, do not distinguish the concentrations of each compound present in the formulation of these additives. 


\subsection{Obtaining root meristem cells of $A$. cepa for cytogenetic analysis}

Bulbs of A. cepa (Common onion, Baia variety) were placed to root in flasks of distilled water at room temperature $\left( \pm 25^{\circ} \mathrm{C}\right)$ and aerated to obtain roots of about $2.0 \mathrm{~cm}$. For analysis of each dose (treatment) an experimental group was established with five onion bulbs. Before placing the roots in contact with their respective doses, some roots were collected and fixed to serve as control $(\mathrm{CO})$ of the bulb itself. The remaining roots were then placed in their respective solutions for 24 hours, a procedure called 24 hour exposure time (24h ET).

After this time some roots were removed and fixed. On completing this procedure, the roots remaining from each bulb were returned to their respective solutions where they remained for 24 hours, which is called the 48 hour exposure time ( $48 \mathrm{~h} \mathrm{ET).} \mathrm{After} \mathrm{this} \mathrm{period,} \mathrm{roots} \mathrm{were} \mathrm{again}$ collected and fixed. Exposure times of 24 and 48 were chosen in order to evaluate the effects of these doses on more than one cell cycle.

In the flask of each bulb under study 1.0 or $2.0 \mathrm{~mL}$ of flavoring (s) to be tested was added, taking care to ensure that all roots were were in adequate contact with the solution under study. The root fixations occurred in Carnoy 3:1 (ethanol:acetic acid) at room temperature for 24 hours. On average, three roots per bulb were removed for each root collection.

\subsection{Preparation and reading of the slides and statistical analysis}

An average of 3 slides per bulb were made following the protocol proposed by Guerra and Souza (2002). Each slide was stained with two drops of $2 \%$ acetic orcein and examined under a light microscope at $40 \mathrm{X}$. For each bulb 1,000 cells were analyzed totaling 5,000 cells for each control and exposure time.

Cells in interphase, prophase, metaphase, anaphase and telophase were observed. The number of cells in interphase and under division, in each control and exposure time was calculated and the mitotic index determined. We also evaluated the action of doses by the number of micronucleated cells in colchicine metaphases, anaphase-telophase bridges, gene amplifications, cells with adhesions, nuclear buds and multipolar anaphases. The data analysis was performed by Chi-square $\left(\chi^{2}\right)$ using the Prism software version 5.0 (GraphPad Software).

\section{Results and Discussion}

Table 1 presents the number of cells in interphase and under different stages of cell division and MI values obtained from meristematic root tissue cells of $A$. cepa treated with water (CO) and Cheese flavor at doses of 1.0 and $2.0 \mathrm{~mL}$ (TR), at ET of 24 and $48 \mathrm{~h}$. The significant $\chi^{2}$ values are presented in the results description.

From the results in Table 1, it was seen that the Cheese flavor, at the two doses, reduced the cell division rate of A. cepa root meristem cells in a statistically significant manner when compared to the MIs obtained from their respective controls, thus presenting as cytotoxic. When considering the MIs, among themselves, of the ETs of the same dose it was found that values were statistically similar. Furthermore, the two doses of this flavoring studied did not promote mitotic spindle abnormalities nor micronuclei in the test the system used. No published papers on the toxicity of this flavoring on the cellular and systemic level have been found.

Table 2, presents the number of undifferentiated cells in interphase and during different phases of cell division and the mitotic index values obtained from the root meristem cells of $A$. cepa treated with water and Cheddar Cheese food flavoring at doses of 1.0 and $2.0 \mathrm{~mL}$ at ETs of 24 and 48 hours. Significant $\chi^{2}$ values were also presented.

The results described in Table 2 showed that the two Cheddar flavor doses evaluated had significant antiproliferative effect at both ETs, as they drastically reduced the A. cepa root tip cell MI when compared with MI data obtained for the respective controls, thus presenting as cytotoxic. It is also possible to observe that at the $1.0 \mathrm{~mL}$ dose cell division rates for the $24 \mathrm{~h}$ ET were statistically higher than MI obtained at $48 \mathrm{~h}$ ET. As for the $2 \mathrm{~mL}$ dose, the MIs, when compared with those obtained for the 24 and 48 ETs, were statistically equal.

Table 1. Number of cells observed for each phase of the cell cycle in meristematic tissue of Allium cepa roots treated with 1.0 or $2.0 \mathrm{~mL}$ of Cheese flavor food flavoring at 24 and 48 hour ETs, and Mitotic Indices obtained for each food flavoring dose evaluated.

\begin{tabular}{lcccccccc}
\hline Flavoring/Dose & ET & $\begin{array}{c}\text { Undifferentiated } \\
\text { Cells/Interphase }\end{array}$ & P & M & A & T & $\begin{array}{c}\text { Cells } \\
\text { under } \\
\text { division }\end{array}$ & MI (\%) \\
\hline \multirow{2}{*}{ Cheese $1 \mathrm{~mL}$} & $\mathrm{CO}$ & 3.888 & 856 & 115 & 93 & 48 & 256 & $5.0^{\mathrm{a}}$ \\
& $24 \mathrm{~h}$ & 4.425 & 498 & 21 & 30 & 26 & 77 & $1.5^{\mathrm{b}}$ \\
& $48 \mathrm{~h}$ & 4.470 & 477 & 23 & 18 & 12 & 53 & $1.1^{\mathrm{b}}$ \\
\hline \multirow{3}{*}{ Cheese $2 \mathrm{~mL}$} & $\mathrm{CO}$ & 4.208 & 595 & 90 & 66 & 41 & 792 & $15.8^{\mathrm{a}}$ \\
& $24 \mathrm{~h}$ & 4.713 & 173 & 69 & 26 & 19 & 287 & $5.7^{\mathrm{b}}$ \\
& $48 \mathrm{~h}$ & 4.667 & 177 & 72 & 59 & 25 & 333 & $6.7^{\mathrm{b}}$ \\
\hline
\end{tabular}

ET - Exposure Time; CO - Control; MI - Mitotic Index; Means followed by the same letter within the same treatment do not differ significantly at $5 \%$ by the $\chi^{2}$ test. 
No changes were observed in the mitotic spindle nor micronuclei in any of the doses evaluated for the flavoring in question. As with the Cheese flavoring, no published papers on the toxicity of Cheddar Cheese flavoring on the cellular and systemic level were found.

In Table 3, the number of interphase cells and at different stages of cell division and MI values obtained from meristematic tissue cells of the roots of Allium cepa treated with water is presented, and with the Cheese and Cheddar Cheese flavors at doses of $0.5 \mathrm{~mL}$ of Cheese flavor associated with $0.5 \mathrm{~mL}$ of Cheddar Cheese flavor; and $1.0 \mathrm{~mL}$ Cheese flavor associated with $1.0 \mathrm{~mL}$ of Cheddar Cheese flavor. Significant $\chi^{2}$ values were also presented in the description of results.

From the results shown in Table 3, it can be seen that in cells treated with $0.5 \mathrm{~mL}$ of Cheese flavor associated with $0.5 \mathrm{~mL}$ of Cheddar Cheese flavor, as well as cells under the treatment with $1.0 \mathrm{~mL}$ Cheese flavor associated with $1.0 \mathrm{~mL}$ of Cheddar Cheese flavor at ETs of 24 and 48 , there was a statistically significant reduction in the cell division rate in relation to MIs obtained for cells treated only with water.

One can also observe that MIs obtained for the $48 \mathrm{~h}$ ET to the two doses of combined flavors studied were significantly lower than those obtained for their respective $24 \mathrm{~h}$ ETs. As such, the combined doses of the two flavorings were highly cytotoxic to the test system in question. Similar to the results obtained for the flavorings tested individually, the doses in combination did not induce cell aberrations.

As shown in Tables 1, 2, and 3, the studied flavorings resulted in toxicity at the lowest manufacturer suggested dose, causing significant changes in the $A$. cepa meristematic root cell cell division rate. As for their evaluation in combination, it was found that in all treatments, the antiproliferative effect is intensified with increasing ET.

Food flavoring, on a systemic level, can be quite toxic when used for prolonged periods, promoting hyperactivity in children with and without attention deficit (Stevens et al., 2014), a significant decrease in hemoglobin concentration in the blood, drastic changes in liver function, a significant decrease in the weight of mice (Shibamoto, 2014), allergies, cutaneous hypersensitivity and poor digestion in humans (Anderson et al., 2013).

However, few studies to date have been conducted to evaluate the toxicity of food flavorings at the cellular level, unlike some dyes used in the food industry, which have been widely studied in different bioassays and have well defined Acceptable Daily Intake (ADI) values. Thus, for food flavorings Honorato et al. (2013) and Curwin et al. (2014) state that these food additives are the least studied regarding cytotoxic potential.

In Brazil, the Agência Nacional de Vigilância Sanitária (ANVISA, 2007) states that high doses of flavorings can cause irritant and narcotic action within the body. They can

Table 2. Number of cells observed for each phase of the cell cycle in meristematic tissue of Allium cepa roots treated with 1.0 or $2.0 \mathrm{~mL}$ Cheddar Cheese flavor food flavoring at 24 and 48 hour ETs, and Mitotic Indices obtained for each dose of food flavoring evaluated.

\begin{tabular}{ccccccccc}
\hline Flavoring & ET & $\begin{array}{c}\text { Undifferentiated } \\
\text { Cells/ Interphase }\end{array}$ & $\mathbf{P}$ & $\mathbf{M}$ & $\mathbf{A}$ & $\mathbf{T}$ & $\begin{array}{c}\text { Cells under } \\
\text { division }\end{array}$ & MI (\%) \\
\hline \multirow{3}{*}{ Cheddar Cheese 1 $\mathrm{mL}$} & $\mathrm{CO}$ & 3575 & 1309 & 187 & 95 & 34 & 1625 & $32.5^{\mathrm{a}}$ \\
& $24 \mathrm{~h}$ & 4158 & 632 & 113 & 54 & 43 & 842 & $16.8^{\mathrm{b}}$ \\
& $48 \mathrm{~h}$ & 4669 & 123 & 101 & 52 & 55 & 331 & $6.6^{\mathrm{c}}$ \\
\hline \multirow{3}{*}{ Cheddar Cheese 2 $\mathrm{mL}$} & $\mathrm{CO}$ & 3303 & 1567 & 73 & 30 & 27 & 1697 & $33.9^{\mathrm{a}}$ \\
& $24 \mathrm{~h}$ & 4557 & 301 & 57 & 41 & 44 & 443 & $8.7^{\mathrm{b}}$ \\
& $48 \mathrm{~h}$ & 4576 & 352 & 40 & 15 & 17 & 424 & $8.5^{\mathrm{b}}$ \\
\hline
\end{tabular}

ET - Exposure Time; CO - Control; MI - Mitotic Index; Means followed by the same letter within the same treatment do not differ significantly at $5 \%$ by the $\chi^{2}$ test.

Table 3. Number of cells observed for each phase of the cell cycle in meristematic tissue of Allium cepa roots treated with $0.5 \mathrm{~mL}$ of Cheese flavor food flavoring associated with $0.5 \mathrm{~mL}$ of Cheddar Cheese food flavoring; and $1.0 \mathrm{~mL}$ Cheese food flavoring associated with $1.0 \mathrm{~mL}$ of Cheddar Cheese food flavoring, at ETs of 24 and 48 hours.

\begin{tabular}{lcccccccc}
\hline \multicolumn{1}{c}{ Flavorings/doses } & ET & $\begin{array}{c}\text { Undifferentiated } \\
\text { Cells/ Interphase }\end{array}$ & $\mathbf{P}$ & $\mathbf{M}$ & $\mathbf{A}$ & $\mathbf{T}$ & $\begin{array}{c}\text { Cells under } \\
\text { division }\end{array}$ & MI (\%) \\
\hline Cheese/ Cheddar Cheese & $\mathrm{CO}$ & 3914 & 851 & 101 & 86 & 48 & 1086 & $21.7^{\mathrm{a}}$ \\
$0.5 \mathrm{~mL}+0.5 \mathrm{~mL}$ & $24 \mathrm{~h}$ & 4786 & 162 & 22 & 14 & 16 & 214 & $4.3^{\mathrm{b}}$ \\
& $48 \mathrm{~h}$ & 4944 & 23 & 19 & 07 & 07 & 56 & $1.1^{\mathrm{c}}$ \\
\hline \multirow{3}{*}{$1.0 \mathrm{~mL}+1.0 \mathrm{~mL}$} & $\mathrm{CO}$ & 3272 & 642 & 42 & 20 & 24 & 1728 & $34.5^{\mathrm{a}}$ \\
& $24 \mathrm{~h}$ & 4476 & 469 & 24 & 16 & 15 & 524 & $10.5^{\mathrm{b}}$ \\
& $48 \mathrm{~h}$ & 4731 & 225 & 24 & 10 & 10 & 269 & $5.4^{\mathrm{c}}$ \\
\hline
\end{tabular}

ET - Exposure Time; CO - Control; MI - Mitotic Index; Means followed by the same letter within the same treatment do not differ significantly at $5 \%$ by the $\chi^{2}$ test. 
also produce long-term chronic toxicity to the digestive tract, when used indiscriminately. However, this regulatory body, as well as EFSA, fails to inform what the acceptable daily intake limits for these additives are and also does not report the doses which are considered high, nor which flavorings cause such damage to the body.

Salinas (2002), states that the use of flavorings in low doses does not cause danger to human health. However, when doses are high, this author states that flavorings can cause irritant and narcotic actions and chronic cellular toxicity over the long term, when used in doses higher than those recommended. However, as with ANVISA (2007), the doses considered ideal for use, as well as those considered toxic, are not specified, nor are the flavorings with such action defined.

Thus, according to Honorato et al. (2013), it appears that although the use of flavoring is permitted by the Ministry of Health and ANVISA, studies are necessary and urgent to determine, with propriety, the toxic potential of these food additives, and thus guide the regulators as well as the food industry to define the IDA for safe use of these chemical compounds.

\section{Conclusion}

From the results obtained in this work there is an urgent need for more studies on the toxicity of these additives at the cellular level in other test systems, especially those using animals, since the $A$. серa bioassay was only the first cytotoxicity screening for Cheese and Cheddar Cheese flavorings.

\section{References}

AGÊNCIA NACIONAL DE VIGILÂNCIA SANITÁRIA ANVISA, 2007 [viewed 8 February 2014]. Resolução da Diretoria Colegiada-RDC no. 05, de 15 de Janeiro de 2007. Diário Oficial da República Federativa do Brasil [online], Brasília, 17 jan. Available from: http://www.anvisa.gov.br/legis/resol/2007/ rdc/02_170107rdc.pdf

ANDERSON, S.E., FRANKO, J., WELLS, J.R., LUKOMSKA, E. and MEADE, B.J., 2013. Evaluation of the hypersensitivity potential of alternative butter flavorings. Food and Chemical Toxicology, vol. 62, no. 1, pp. 373-381. http://dx.doi.org/10.1016/j. fct.2013.08.053. PMid:24007741.

ARUNG, E.T., FURUTA, S., ISHIKAWA, H., TANAKA, H., SHIMIZU, K. and KONDO, R., 2011. Melanin biosynthesis inhibitory and antioxidant activities of quercetin-3'-O-beta-D-glucose isolated from Allium cepa. Zeitschrift fur Naturforschung C. Journal of Biosciences, vol. 66, no. 5-6, pp. 209-214. PMid:21812337.

CARITÁ, R. and MARIN-MORALES, M.A., 2008. Induction of chromosome aberrations in the Allium cepa test system caused by the exposure of seeds to industrial effluents contaminated with azo dyes. Chemosphere, vol. 72, no. 5, pp. 722-725. http:// dx.doi.org/10.1016/j.chemosphere.2008.03.056. PMid:18495201.

CHEESEMAN, M.A., 2012. Artificial food color additives and child behavior. Environmental Health Perspectives, vol. 120, no. 1, pp. 15-16. http://dx.doi.org/10.1289/ehp.1104409. PMid:22214569.

CONSTANT, P.B.L., STRINGUETA, P.C. and SANDI, D., 2007. Corantes alimentícios. Boletim Centro de Pesquisa de Processamento de Alimentos, vol. 20, no. 2, pp. 203-220.

CURWIN, B.D., JIM, A.D. and LAURALYNN, T.M., 2014. Flavoring exposure in food manufacturing. Journal of Exposure Science \& Environmental Epidemiology, vol. 25, no. 3, pp. 324333. PMid:25052692.

GOMES, K.M., PERON, A.P., AGUIAR, V.M. and CARVALHO, F.R., 2013. Citotoxicity of food dyes sunset yellow (E-110), bordeaux red (E-123), and tatrazine yellow (E-102) on Allium cepa L. root meristematic cells. Ciência e Tecnologia de Alimentos, vol. 33 , no. 3 , pp. 218-223.

GUERRA, M. and SOUZA, M.J., 2002. Como observar os cromossomos: um guia de técnicas em citogenética vegetal, animal e humana. Ribeirão Preto: FUNPEC.

HERRERO, O., PÉREZ MARTÍN, J.M., FERNÁNDEZ FREIRE, P., CARVAJAL LÓPEZ, L., PEROPADRE, A. and HAZEN, M.J., 2012. Toxicological evaluation of three contaminant of emerging concern by use of Allium cepa test. Mutation Research, vol. 743, no. 1-2, pp. 20-34. PMid:22249112.

HONORATO, C.T., BATISTA, E., NASCIMENTO, O.K. and PIRES, T., 2013. Aditivos alimentares: aplicações e toxicologia. Revista Verde, vol. 8, no. 5, pp. 1-11.

IGANCI, J.R.V., BROBOWSKI, G., HEIDEN, G.V.C., STEIN, L. and ROCHA, B.H.G., 2006. Efeito do extrato aquoso de diferentes espécies de boldo sobre a germinação e índice mitótico de Allium cepa L. Arquivos do Instituto Biologico, vol. 73, no. 1, pp. 79-82.

OLIVEIRA, M.V.A., ALVES, D.D.L., LIMA, L.H.G.M., CASTRO, J.M. and PERON, A.P., 2013. Citotoxicidade dos corantes alimentares erythrosine (E-127), azul brilhante (E-133) e red 40 (E-129) em sistema-teste vegetal. Acta Scientiarum Biological Science, vol. 35 , no. 4, pp. 557-562.

SALINAS, R.D., 2002. Alimentos e nutrição: introdução a bromatologia. Porto Alegre: The Art of Medication.

SHIBAMOTO, T., 2014. Diacetyl: occurence, analysis and toxicity: a review. Journal of Agricultural and Food Chemistry, vol. 62, no. 18, pp. 4048-4053. http://dx.doi.org/10.1021/jf500615u. PMid:24738917.

STEVENS, L.J., BURGESS, J.R., STOCHELSKI, M.A. and KUCZEK, T., 2014. Amounts of artificial food dyes and added sugars in foods and sweets commonly consumed by children. Clinical Pediatrics, vol. 54, no. 4, pp. 309-321. PMid:24764054.

TABREZ, S., SHAKIL, S., UROOJ, M., DAMANHOURI, G.A., ABUZENADAH, A.M. and AHMAD, M., 2011. Genotoxicity testing and biomarker studies on surface water: an over view of the techniques and their efficacies. Environmental Carcinogenesis Ecotoxicology Review, vol. 29, no. 3, pp. 250-275. http://dx.doi. org/10.1080/10590501.2011.601849. PMid:21929382. 